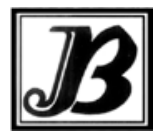

J. Bio-Sci. 28: 95-103, 2020

ISSN 1023-8654

http://www.banglajol.info/index.php/JBS/index

DOI: https://doi.org/10.3329/jbs.v28i0.44715

\title{
PREVALENCE AND PCR BASED MOLECULAR CHARACTERIZATION OF GOAT POX VIRUS FROM FIELD OUTBREAKS OF MULTAN AND BAHAWALNAGAR, PAKISTAN
}

\author{
A ljaz ${ }^{*}$, F Jabeen, A Ashraf and S Naz \\ Department of Zoology, Government College University Allama Iqbal Road 38000, Faisalabad, Pakistan
}

\begin{abstract}
This study was designed to check the prevalence and PCR-based molecular characterization of goat pox virus (GTPV) in the Multan and Bahwalnagar regions of Punjab, Pakistan. Capripox virus (CPPV) is the cause of goat pox (GTP) and sheep pox (SPP) disease, it highly affects the morbidity and mortality rate of goats and sheep. In this study, the 80 tissues and blood samples of goats were collected on age basis from the goat farms, slaughter houses, tanneries and domestic animals. The epidemiological data was also collected. The collected samples were processed for DNA extraction. We characterized the goat pox virus (GTPV) with specific primers of P32 gene by PCR. Then each amplified product was analyzed by agarose gel electrophoresis visualized by UV fluorescence light. This study showed that Infants of goats (2-10 months) in Multan showed 25\% while adult goat in Multan showed $14.2 \%$ positive results. In Bahawlnagar, the affected infants of goats (2-10 months) found were $31.25 \%$ while adult infected goats were $11.1 \%$. Both primers were equally effective for the characterization of unknown samples. The most effected goats were adult female and infants.
\end{abstract}

Key words: CPPV, GTPV, GTP, SPP, SPPV, P32

\section{Introduction}

Domesticated animal play significant roles in the economy of Pakistan and contribute around $56 \%$ in development agribusiness and around $11 \%$ to the GDP. Animals incorporate the cows, wild oxen, sheep and goat (Rehman et al. 2017). The flexibility of goats to various conditions and flawless association results to extend their world, under which those animals create and spare themselves. Pakistan is third most prominent country with relevancy glut of goats after China and India and having 66.6 million heads. While Pakistan is at fourth position in goat's gutter and sheep growing international locations with each year generation of 822 thousand tons of drain and 657 thousand tons of meat (Aziz 2010). Disease predominance is affected by organic framework, physiographic, soil sorts, precipitation, temperature and relative moistness (Bhanuprakash et al. 2006). SPP and GTP virus might be inactivated at $65^{\circ} \mathrm{C}$ within 30 minutes or $56^{\circ} \mathrm{C}$ within $2 \mathrm{~h}$. They can make infection at a pH in range of 8.6 and 6.6. These viruses are inclined to particularly acidic or basic pH; $2 \% \mathrm{HCl}$ can crush these viruses within 15 min (Yeruham et al. 2007, Yune and Abdela 2017).

Animals are helpless all through all age associations, and it has an exceptionally vital part in agrarian monetary framework. From the field of announced ailment flare-ups, it was learnt that the ailment could not be seen in immunized papules however saw in unvaccinated animals (Roy et al. 2018).GTP infection is

\footnotetext{
*Author for correspondence: ayeshaijaz@gcuf.edu.pk
} 
transmitted by contact with infected animals, their vaporizers, nasal release, salivation or dried scabs. The infections are also promptly transported on garments. Some insects e.g. the stable fly (Stomoxys calcitrans) act occasionally as mechanical vectors. Epidemiology of the ailment is likewise essential in diagnoses of SPP and GTP. Developing life clearing and auxiliary pneumonia are also viewed on the complexities (Juneja and Ganguly 2017, Yune and Abdela 2017). Movements of infected animals act as principle source of spreading infections. SPPV and GTPV may make critical harm fleece and covers up, diminished lamb and drain creation (Babiuk et al. 2008). The death rate of sheep and goat will currently and again be significantly high, among sheep and grown-ups (Tuppurainen et al. 2017). CPPV cause high mortality and morbidity rate in dairy cattle, goats and sheep (Sajid et al. 2013). The disease is basic both in stormy and winter season; however, the death rate is highest in the stormy season due to the rapid transmission of virus. It was also likewise watched that $33.33 \%$ disease was in roaming groups and 10\% in settled crowds (Massoud et al. 2016). As of late landowners of Tharparkar and its encompassing zones have endured immense financial misfortunes as death of thousands of sheep because of this disease. Unstable and specific nuclear procedures are used for acknowledgment of CPPV concentrating on the RPO30, P32 and GPCR characteristics (Zhou et al. 2012). It is understood that heterogonous diagnostic reagents tend to be less productive than homologous reagents for corroborative finding (Yune and Abdela 2017). Prognosis of SPP is often supported extraordinarily function clinical symptoms ELISA check virus neutralization test, virus isolation (Tian et al. 2010) and PCR measures (Balinsky et al. 2008, Adedeji et al. 2019).

In previous studies the seroepidemiology data of goats were studied only in district Layyah Punjab Pakistan (Masoud et al. 2016). In another study the prevalence was checked in the areas of Punjab Pakistan and its needed to further plan the study to control and eradicate this disease by control measure and by proper vaccination (Sajid et al. 2012). In further study we should do cloning and should find the way to control this disease in goats. The objective of this study is to check the prevalence of Goat pox disease in Multan and Bahwalnagar regions and molecular characterization of goat pox virus by PCR. The PCR test has enormous potential for the discovery of pathogens and for the most part utilized as the touchy and corroborative determination of the personality of the illness. The utilization of PCR strategy for SPP and GTP infection distinguishing proof thought to be a basic, quick and indicative technique.

\section{Materials and Methods}

\section{Ethical approval}

As per the committee for control and supervision of experiments on animal's guidelines, studies involving the collection of field clinical samples do not require any approval from the Institute's Ethics Committee. Study areas and sample collection. The present study was designed to collect the samples of infected goats based on age and characterize them by PCR from Multan and Bahawalnagar regions of Punjab, Pakistan. The samples were collected from different hides, slaughterhouses and goat markets from Multan and

Bahawalnagar regions. It comprises five administrative units, Minchan Abad, Chishtian, Fort Abbas, Haroon Abad, and Bahawalnagar. 
Blood samples, hair samples, and skin tissues were collected from the animals showing typical signs and symptoms of goat pox disease. About 80 samples were collected from infected goats present in different herds. Blood samples were collected in EDTA tubes and tissue samples were collected in SDS solution without EDTA tubes. By following Biosafety procedures all the samples were stored in the icebox and brought to GCUF Zoology Research Laboratory through proper transportation and packaging. The collected samples were centrifuged on $10000 \mathrm{rpm}$ for just one minute so, the debris was settled down and a clear solution was used for the further process. Viral DNA was isolated from collected samples by following the procedure of (Sambrock et al. 1989).

\section{The DNA extraction method}

Fifty $\mu \mathrm{l}$ from each collected sample was taken in Eppendorf tubes and homogenization was carried out by using $400 \mu \mathrm{l}$ TAE buffer. Then added $400 \mu \mathrm{l}$ of $20 \%$ SDS and $100 \mu \mathrm{l}$ of $20 \mathrm{mg} / \mathrm{ml}$ proteinase K. After Incubation, for 4 hours at $55^{\circ} \mathrm{C}$ these tubes were vortexed for $15-30 \mathrm{sec}$. The supernatant was taken after 10 min centrifugation and transferred to another tube. DNA was precipitated by adding $300-400 \mu$ l of isopropanol or super cold $100 \%$ ethanol and kept at $-4^{\circ} \mathrm{C}$ for 60 minutes. Centrifuged again for 10 minutes. Pellet was washed with $70 \%$ ethanol and was dried for 10-15 minutes. DNA was permitted to suspend in $25 \mu \mathrm{l}$ of sterile water $\left(\mathrm{d}_{3} \mathrm{H}_{2} \mathrm{O}\right)$ for further processing. Nanodrop was used for the DNA quantification (Bowden et al. 2008).

\section{Primers}

A conserved region of P32 gene was used for the detection of GTPV. The following table shows the sequence and nucleotide position of the reported primer used in this study (Bowden et al. 2008) (Table 1).

Table 1. Reported and designed primers of goat pox virus

\begin{tabular}{llcc}
\hline $\begin{array}{l}\text { General primers } \\
\text { of goat pox }\end{array}$ & Sequence $\left(5^{\prime}-3^{\prime}\right)$ & $\begin{array}{c}\text { PCR product } \\
\text { (bp) }\end{array}$ & Reference \\
\hline (P1) Forward & $5^{\prime}$-CTAAAATTAGAGACTATACTTCTT-3' & & \\
(P2) Reverse & $5^{\prime}$-CGATTTCCATAAACTAAAGTG-3' & 969 bp & $\begin{array}{c}\text { Bowden et al. } \\
(2008)\end{array}$ \\
\hline
\end{tabular}

\section{PCR conditions and reactions}

For PCR of random amplified Polymorphic DNA analysis, the concentration of genomic DNA $10 \times$ PCR buffer with $\left(\mathrm{NH}_{4}\right)_{2} \mathrm{SO}_{4}$, $\mathrm{MgCl}_{2}$, dNTPs, 10-mer random primer and DNA Taq Polymerase were optimized. The 10 base oligonucleotide primers used for amplification of genomic DNA were obtained from Gene link Company. PCR was conducted in $50 \mu \mathrm{I}$ PCR tubes containing the $25 \mu \mathrm{l}$ master mixture. PCR reaction was done in Persona Autorisieter Master cycler of the Eppendorf, Germany. The PCR for goat pox virus were performed by using $10 \mu \mathrm{l}$ of template placed in $50 \mu \mathrm{l}$ of the ultimate extend of a $10 \mathrm{X}$ reaction mixture containing $50 \mathrm{mM}$ $\mathrm{KCl}, 10 \mathrm{mM}$ Tris- $\mathrm{HCl}, 1.5 \mathrm{mM} \mathrm{MgCl}, 200 \mathrm{mM}$ of dNTP and $100 \mathrm{pmol}$ of primer sets for the gene encoding for the viral attachment protein as described by (Ireland and Binepal 1998) and 2U Taq-DNA polymerase. Amplification consisted of an initial denaturation step at $94^{\circ} \mathrm{C}$ for $4 \mathrm{~min}$, which will be followed by 35 cycles at $47^{\circ} \mathrm{C}$ for $1 \mathrm{~min}, 72^{\circ} \mathrm{C}$ for $1 \mathrm{~min}, 95^{\circ} \mathrm{C}$ for $45 \mathrm{sec}$ and, finally, extension at $72^{\circ} \mathrm{C}$ for $10 \mathrm{~min}$ in a thermal cycler. 
PCR products were visualized in $1 \%$ agarose gel containing ethidium bromide. PCR products were evaluated on 1.5\% agarose gel prepared in TAE buffer. DNA samples were then loaded with DNA loading buffer. The gel was run out at 120 volts for about 30-40 minutes. The gel has been examined under ultraviolet Transilluminator and photographed using a gel documentation system (WEALTEC, Dolphin-Doc) (Chopade et al. 2013).

\section{Results}

The clinical signs of GTP were found in the form of pustules, papules, nodules, and scabs mostly on the hairless areas such as groin and perineum in addition to nose, eyes and lips making the feed intake painful. It was found that overall prevalence of CPPV was more in Bahawalnagar, as we found the affected animal which shows the typical signs have prevalence of $24 \%$ and in Multan 20\%. This above percentage showed the combined effect of the CPPV on sheep and goat. While the separate effect shows some differences regarding the percentage. Infants of goats in Multan showed 25\% positive results while adult goat in Multan showed $14.2 \%$ positive results. In Bahawalnagar, the affected infants of goats found are $31.25 \%$ while adult goats with positive signs are $11.1 \%$ (Table 2).

Table 2. PCR based detection of virus from suspected samples collected from different herds and Slaughter houses

\begin{tabular}{|c|c|c|c|c|c|c|c|c|}
\hline \multirow[t]{2}{*}{ Species } & \multicolumn{3}{|c|}{ Multan } & $\%$ & \multicolumn{4}{|c|}{ Bahawalnagar } \\
\hline & \multicolumn{3}{|c|}{ Samples } & & \multicolumn{3}{|c|}{ Samples } & \% Positive \\
\hline \multirow{2}{*}{$\begin{array}{c}\text { Infant goats } \\
\text { (2-10 } \\
\text { months) }\end{array}$} & & Infected & Healthy & \multirow[b]{2}{*}{$25 \%$} & \multirow[b]{2}{*}{32} & Infected & Healthy & \multirow[b]{2}{*}{$31.25 \%$} \\
\hline & 16 & 4 & 12 & & & 10 & 22 & \\
\hline Adult goat & 14 & 2 & 12 & $14.2 \%$ & 18 & 2 & 16 & $11.1 \%$ \\
\hline Total & \multicolumn{3}{|l|}{30} & $20 \%$ & \multicolumn{3}{|c|}{50} & $24 \%$ \\
\hline
\end{tabular}

The PCR measure was observed delicate and the exactness and unwavering quality was affirmed by sequencing the relating amplicons of GTPV field disengage accessible for this examination (Fig. 3 and 4). The flow thinks about recommended that the two preliminaries of P32 and other quality can be utilized for atomic recognizable proof of GTP malady. The accessibility of a simple to-utilize sub-atomic technique is required for the distinguishing proof of CPPV. The distinguishing proof of appropriate focus in the viral genome of P32 to separate antibody strains from GTPV field disengages incredibly decreases the expenses, by permitting the sequencing of little genome pieces. The present test is expected to be utilized by every veterinary research facility, incorporating those with constrained assets. It can also be utilized as a lead instrument for the immediate screening of neurotic examples gathered in CPPV flare-ups, particularly those happening in already immunized little ruminant populaces. (Fig. 1 and 2). 


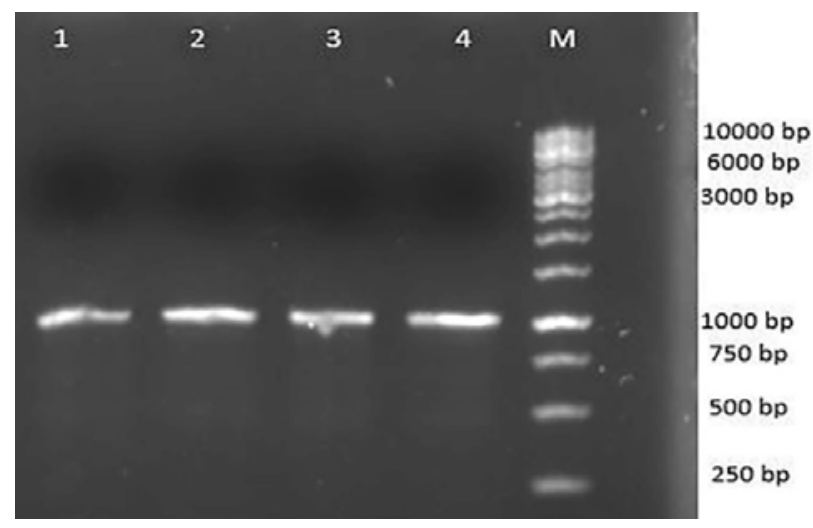

Fig. 1. Agarose gel showing 969 bp PCR product of p32 gene of Capri pox virus using P1 and P2 primers (Lane 1- 4: positive samples, Lane M: $1 \mathrm{~Kb}$ ladder)

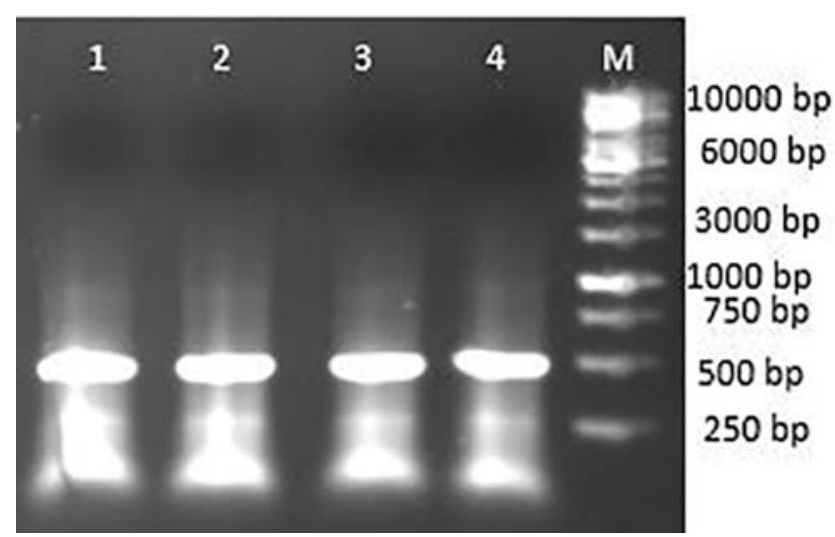

Fig. 2. Agarose gel showing 530 bp PCR product of p32 gene of Capri pox virus using S1 and S2 primers (Lane 1- 4: positive samples, Lane M: 1Kb ladder)

\section{Discussion}

Goat Farming is incredible and popular business model in Pakistan and about 66.6 million goat population recorded per economic survey of 2016. CPPV contamination of sheep and goat effects in most important monetary losses and it also hinders the worldwide trade (Anonymous). In Pakistan, the disease is primary in arid regions accompanied by southern and northern regions of Punjab Pakistan (Sajid et al. 2012).

The current study of CPPV based on the prevalence and characterization of SPPV and GTPV in the areas of Pakistan. SPPV and GTPV are endemic in some countries. These viruses can easily be diagnosed clinically as SPPV and GTPV, but it cannot differentiate at field level. Although, there are many reports of CPPV outbreak and prevalence in goats and sheep and their causative agents. But there is a need to identify causative agents properly in outbreaks of CPPV. There are some game animals play role in maintaining and 
cause an outbreak of CPPV for the identification and differentiation of GTPV, SPPV and LSDV, the phylogenetic analysis used in many studies. CPPV, RPO30, PCR used for the fast differentiation of GTPV and SPPV without using the technique of gene sequencing. Mahmoud and Khafgi (2016) used the speciesspecific primer, CPPV RPO30 PCR method to detect and identify the infection. Their results declared that the sequencing RPO30 gene-based PCR assay give a good picture of molecular epidemiology of CPPV infection.

In Previous study P32 primer was used for the detection of GTPV by PCR method Bora et al. (2018). P32 primer was also used for differentiation of GTPV, SPPV, and LSDV by PCR method (Shehbaz and Hussain 2017). It was also found that the PCR assay developed a specific and sensitive method for differentiation and detection of infection in SPPV and GTPV (Zhou et al. 2012). It was declared that the PCR and EM are a rapid and sensitive method for differentiation and characterization or identification of SPPV and GTPV (AbdElfatah et al. 2018, Adedeji et al. 2019). As many other studies concluded that the P32 primer and PCR methods are the best parameters used ever for the phylogenetic analysis and use of RPO30 gene-based PCR assay used for molecular epidemiology (Yan et al. 2012, Santhamani et al. 2013, Venkatesan et al. 2010, 2014 \& 2016, Mahmoud and Khafgi 2016, Zhao et al. 2014 \& 2017, Karapinar et al. 2017, Roy et al. 2018).

It was found that the clinical signs of GTP may be variable. Skin lesions are seen and characterized by papules, nodules, pustules, and scabs. Overall prevalence of CPPV was more in Bahawalnagar as we found the affected animals which have prevalence of $24 \%$ and in Multan 20\%. This above percentage showed the combined effect of CPPV on adult goat and infant goat. While the separate effect shows some differences regarding the percentage. Infant Goats in Multan showed 25\% positive results while adult goats in Multan showed $14.2 \%$ positive results. In Bahawalnagar, the affected infant goats found are $31.25 \%$ while adult goat with positive signs is $11.1 \%$. The samples were characterized first by reported primers. P1 and P2 primer pair yield a PCR product of 969 bp representing the P32 gene. Then newly designed primer was also checked and found that these primers are also giving good results, while new designed S1and S2 primer yielded a PCR product of $530 \mathrm{bp}$. Disease caused by CPPV is important causes of economic loss in goat and sheep farming. It was determined that $33.33 \%$ disease was in nomadic herds and $10 \%$ in settled herds (Masoud et al. 2016). Farmers of Tharparkar and its surrounding areas have suffered huge economic losses in the form of death of thousands of sheep due to this disease.

Based on the results of the present study following conclusion are drawn: $P 32$ gene is an important gene used for characterization of GTPV. Specific primers are used which gives 969 bp product of PCR. Also, the newly designed primer has given 530 bp product of PCR. Both reported, and newly designed primers showed positive results for identification of GTPV and negative as normal skin samples. The seasonal calendar of GTPV was outlined by informant groups and it was claimed to occur during the long and short rainy seasons of a year. Furthermore, GTP was listed to be one of the most common five goat diseases in the area by the farmers. Generally, the disease and associated morbidity and mortality were less commonly seen in adult age groups as compared to young age groups. P32 is the major immune dominant gene having amplicon size of 1024 bp and 1027 bp in GTPV and SPPV respectively. Also, P32 is gene sequencing data widely used for differentiating SPPV and GTPV and phylogenetic analysis of CPPV (Zhou et al. 2012). Several researchers used the P32 gene to detect SPV and GPV because it contains a most significant antigenic determinant present in all species of CPPV genus (Tian et al. 2010). Based on P32 gene analysis, 
it used to be determined the GTPV sequences are all most conserved. From the field of stated disorder outbreaks, it was once learned that the disease may want to no longer be determined in vaccinated populations but observed in unvaccinated animals (Roy et al. 2018).

\section{Conclusion}

The results of this study showed that disease mostly prevailed in Bahawalnagar (24\%) than Multan (20\%). We declare this \% age by using gene sequencing of $P 32$. The animals were declared positive based on the PCR test. The normal skin samples were also preceded for negative control, but the virus was not detected, and vaccination of blood samples was taken as positive control. PCR was optimized for detection of Capri pox virus using specific primers. The samples were characterized first by reported primers.P1 and P2 primer pair yield a PCR product of 969 bp representing the P32 gene. Then newly designed primer was also checked and found that these primers are also giving good results, while new designed S1and S2 primer yielded a PCR product of $530 \mathrm{bp}$. After conducting the study, we reach a point that the major factor in the spread of the disease was a movement of nomadic peoples along with their animals in different areas. It can be controlled by the carpet vaccination at the entry point and damping down vaccination in the endemic areas. Similarly, a bivalent vaccine of Capripox can give good results.

\section{Acknowledgment}

Authors are highly thankful to the farmers and the person who helped during the sample collection across the cities. We are heartedly thankful to HEC for funding as this is the part of the research program of the HEC project No. 4760.

\section{References}

Abd-Elfatah EB, El-Mekkawi MF, Bastawecy IM and Fawzi EM (2018). Identification and phylogentic analysis of sheep pox during an outbreak of sheep in Sharkia Governorate, Egypt. doi.org/10.4238/gmr16039901.

Adedeji AJ, Moller J, Meseko CA, Adole JA, Tekki IS, Shamaki D and Hoffmann B (2019). Molecular characterization of Capripox viruses obtained from field outbreaks in Nigeria between 2000 and 2016. Transboundary and emerging diseases. doi.org/10.1111/tbed.13197.

Aziz MA (2010). Present status of the world goat populations and their productivity. World, 861(1078.2), 1.

Babiuk S, Bowden TR, Boyle DB, Wallace DB and Kitching RP (2008). Capripoxviruses: an emerging worldwide threat to sheep, goats and cattle. Transboundary and Emerging Diseases, 55(7): 263-272.

Balinsky CA, Delhon G, Smoliga G, Prarat M, French RA, Geary SJ and Rodriguez LL (2008). Rapid preclinical detection of sheeppox virus by a real-time PCR assay. Journal of Clinical Microbiology, 46(2): 438-442.

Bhanuprakas, V, Indrani BK, Hosamani M and Singh RK (2006). The current status of sheep pox disease. Comparative Immunology, Microbiology and Infectious Diseases, 29(1): 27-60.

Bora DP, Venkatesan G, Neher S, Mech P, Barman NN, Ralte E, Das SK (2018). Goatpox outbreak at a high altitude goat farm of Mizoram: possibility of wild life spill over to domestic goat population. Virus Disease, 29(4): 560-564.

Bowden TR, Babiuk SL, Parkyn GR, Copps JS and Boyle DB (2008). Capripoxvirus tissue tropism and shedding: A quantitative study in experimentally infected sheep and goats. Virology, 371(2): 380-393. 
Chopade NA, Kaore MP, Chavan CA, Rautmare SS, Tembhurne PA, Bhandarkar AG and Kurkure NV (2013). Detection of Capripoxvirus from Field Outbreak of Sheep Pox in Maharashtra State by Polymerase Chain Reaction. Indian Vet. Journal, 90(3): 110-111.

Ireland DC and Binepal YS (1998). Improved detection of capripoxvirus in biopsy samples by PCR. Journal of Virological Methods, 74: 1-7.

Juneja R and Ganguly S (2017). Sheep pox and goat pox: the animal diseases of importance for transboundary control. International Journal, 3(1): 30.

Karapinar Z, Ilhan F, Dincer E and Yildirim S (2017). Pathology and phylogenetic analysis of Capripox virus in naturally infected sheep Sheep pox virus. Pakistan Veterinary Journal, 37(1): 2074-7764

Lamien CE, Lelenta M, Goger W, Silber R, Tuppurainen E, Matijevic M and Diallo A (2011). Real time PCR method for simultaneous detection, quantitation and differentiation of capripoxviruses. Journal of Virological Methods, 171(1): 134-140.

Mahmoud MA and Khafagi MH (2016). Detection, identification, and differentiation of sheep pox virus and goat pox virus from clinical cases in Giza Governorate, Egypt. Veterinary World, 9(12): 1445.

Massoud AH, Charbonnier LM, Lopez D, Pellegrini M, Phipatanakul W and Chatila TA (2016). An asthma-associated IL4R variant exacerbates airway inflammation by promoting conversion of regulatory $\mathrm{T}$ cells to $\mathrm{T} \mathrm{H}$ 17-like cells. Nature Medicine, 22(9): 1013.

Rehman A, Jingdong L, Chandio AA and Hussain I (2017). Livestock production and population census in Pakistan: Determining their relationship with agricultural GDP using econometric analysis. Information Processing in Agriculture, 4(2): 168-177

Roy P, Jaisree S, Balakrishnan S, Senthilkumar K, Mahaprabhu R, Mishra A and Karmakar AP (2018). Molecular epidemiology of goat pox viruses. Transboundary and Emerging Diseases, 65(1): 32-36.

Sajid A, Chaudhary ZI, Maqbol A, Anjum AA, Sadique U, Hassan ZU and Shahid M (2013). Comparative sensitivity of PCR and cell culture technique for the identification of goat pox virus. J. Anim. Plant Sci., 23(1): 31-34.

Sajid A, Chaudhary ZI, Sadique U, Maqbol A, Anjum AA, Qureshi MS and Shahid M (2012). Prevalence of goat pox disease in Punjab province of Pakistan. J. Anim. Plant Sci., 22 (2): 28-32.

Sambrock J (1989). In vitro amplification of DNA by the polymerase chain reaction. Molecular Cloning, A Laboratory Manual, 2: 1418-1419.

Santhamani R, Yogisharadhya R, Venkatesan G, Shivachandra SB, Pandey AB and Ramakrishnan MA (2013). Detection and differentiation of sheep pox virus and goatpox virus from clinical samples using $30 \mathrm{kDa}$ RNA polymerase subunit (RPO30) gene based PCR. Veterinary World, 6(11): 923-925.

Selvaraju G (2014). Epidemiological measures of disease frequency against sheep pox. International Journal of Scientific Research, 8(2): 2277-8179.

Shehbaz HA and Hassan IQ (2017). Phylogenetic analysis of sheep pox virus isolates based on P32 gene in Iraq. Journal of Entomology and Zoology Studies, 5 (6): 704-708.

Tian H, Chen Y, Wu J, Shang Y and Liu X (2010). Serodiagnosis of sheep pox and goat pox using an indirect ELISA based on synthetic peptide targeting for the major antigen P32. Virology Journal, 7(1): 245.

Tuppurainen ESM, Venter EH, Shisler JL, Gari G, Mekonnen GA, Juleff N and Babiuk S (2017). Capripoxvirus diseases: current status and opportunities for control. Transboundary and Emerging Diseases, 64(3): 729-745. 
Venkatesan G, Balamurugan V, Bhanuprakash V, Singh RK and Pandey AB (2016). Loop-mediated isothermal amplification assay for rapid and sensitive detection of sheep pox and goat pox viruses in clinical samples. Molecular and Cellular Probes, 30(3): 174-177.

Venkatesan G, Balamurugan V and Bhanuprakash V (2014). Multiplex PCR for simultaneous detection and differentiation of sheep pox, goat pox and or viruses from clinical samples of sheep and goats. Journal of Virological Methods, 195: 1-8.

Venkatesan G, Balamurugan V, Singh RK and Bhanuprakash V (2010). Goat pox virus isolated from an outbreak at Akola, Maharashtra (India) phylogenetically related to Chinese strain. Tropical Animal Health and Production, 42(6): 1053-1056.

Yan XM, Chu YF, Wu GH, Zhao ZX, Li J, Zhu HX and Zhang Q (2012). An outbreak of sheep pox associated with goat poxvirus in Gansu province of China. Veterinary Microbiology, 156(3-4): 425-428.

Yeruham I, Yadin H, Van Ham M, Bumbarov V, Soham A and Perl S (2007). Economic and epidemiological aspects of an outbreak of sheep pox in a dairy sheep flock. The Veterinary Record, 160(7): 236-237.

Yune $N$ and Abdela N (2017). Epidemiology and economic importance of sheep and goat pox: a review on past and current aspects. J. Vet. Sci. Technol., 8(430): 2.

Zangana IK and Abdullah MA (2013). Epidemiological, clinical and histopathological studies of lamb and kid pox in Duhok, Iraq. Bulgarian Journal of Veterinary Medicine, 16(2): 133-138.

Zhao Z, Fan B, Wu G, Yan X, Li Y, Zhou X and Li J (2014). Development of loop-mediated isothermal amplification assay for specific and rapid detection of differential goat pox virus and sheep pox virus. BMC Microbiology, 14(1): 10.

Zhao Z, Wu G, Yan X, Zhu X, Li J, Zhu H and Zhang Q (2017). Development of duplex PCR for differential detection of goat pox and sheep pox viruses. BMC Veterinary Research, 13(1): 278.

Zhou T, Jia H, Chen G, He X, Fang Y, Wang X and Jing Z (2012). Phylogenetic analysis of Chinese sheep pox and goat pox virus isolates. Virology Journal, 9(1): 25.

(Manuscript received on July 07, 2019 and revised on November 13, 2019) 
ljaz et al. 